\title{
Psikolojik Danışmanlık ve Rehberlik Lisans Programı Öğrencilerinin Bu Programı Tercih Nedenlerinin İncelenmesi $^{1}$
}

DOI: $10.26466 /$ opus.667847

\author{
Feride Bacanl1* - Abdullah Mücahit Aslan ** \\ * Prof. Dr., Gazi Üniversitesi, Gazi Eğitim Fakültesi, Ankara/Türkiye \\ E-Posta: fbacanli@gazi.edu.tr \\ ORCID: 0000-0001-8008-8441 \\ ** Arş.Gör., Gazi Üniversitesi, Gazi Eğitim Fakültesi, Ankara/Türkiye \\ E-Posta: abdullahmucahit71@hotmail.com \\ ORCID: $0000-0001-7468-6103$
}

Öz

Bu araştırmanın amacı, Psikolojik Danışmanlık ve Rehberlik (PDR) anabilimdaki birinci sımı öğrencilerinin PDR programını tercih nedenlerini incelemektir. Çalışma grubu, 10 farklı üniversitenin PDR ana bilim dalında öğrenime yeni başlayan 200 (kadın ve erkek) öğrenciden oluşmaktadır. Bu araştırmada nitel araştırma yöntemlerinden fenomenoloji deseni kullanılmıştır. Araştırma verileri araştırmacılar tarafindan geliştirilen 10 açık uçlu sorudan oluşan soru formu kullanılarak toplanmıştır. Veriler içerik analizi kullanılarak analiz edilmiştir. Araştırmanın sonuçlarına göre katılımcılar, psikolojik danışmanları okullarda psikolojik destek sunan kişiler olarak görmektedirler. Psikolojik danışmanların okul dışında daha çok adliye ve özel şirketlerde çalıştıklarını belirtmişlerdir. Rehber öğretmen kavramını, okullarda görev yapan kişiler olarak algilarlarken; psikolojik danışman kavramın ise okulların dışında yetişkinlerle çalışan psikoloji mezunu kişiler olarak algilamaktadırlar. Katılımcıların çoğu PDR programinı birinci sırada tercih etmişlerdir. Tercih sürecinde en fazla okul psikolojik danışmanlarından ve aile üyelerinden bilgi ve destek kaynă̆ı olarak yararlanmışlardır. PDR programın tercih etme nedenleri olarak ilk stralarda kişisel faktörleri ifade etmişlerdir. Bunu politik, ekonomik ve eğitim sistemiyle ilgili faktörlerin ve sosyal faktörlerin izlediği görülmüştür. Araştırmanın sonuçlarn ilgili literatüre dayanılarak tartışılmıştır. Araştırmanın sınırlılıkları ve gelecekte yapılacak araştırmalar için öneriler sunulmuştur.

Anahtar Kelimeler: Psikolojik danışmanlık ve rehberlik, kariyer psikolojik danışmanlığı, tercih nedenleri

\footnotetext{
${ }^{1}$ Bu makalenin ilk versiyonu 20. Uluslararası Psikolojik Danışma ve Rehberlik Kongresi'nde sözel bildiri olarak sunulmuştur. 25-27 Ekim 2018, Canik Kültür Merkezi, Samsun/Türkiye.
} 


\title{
Examining Preference Reasons of Undergraduate Students In Psychological Counseling and Guidance Programme
}

\begin{abstract}
The aim of this study is to determine the reasons why undergraduate first year students in the Psychological Counseling and Guidance (PDR) program prefer PDR. The study group consists of 200 (women and men) students who have just started to study in the PDR department of 10 different universities. The phenomenology design from qualitative research methods is used in this research. The research data were collected using a questionnaire consisting of 10 open-ended and closed-ended questions developed by the researchers. Data were analyzed using content analysis. According to the results of the research, psychological counselors are seen by the participants as psychological supporters in schools. They stated that psychological counselors worked outside the school in courthouses and private companies. While perceiving the concept of guidance teacher in the context of school, teacher and student; the concept of psychological counselors is perceived as psychology graduates working with adults and outside school. Most of the participants preferred the PDR program in the first place. They mostly benefited from school psychological counselors and family members as a source of information and support during the choice process. The participants expressed personal factors as the reasons for preference the PDR program. This was followed by political, economic and educational factors and social factors. The results of the research were discussed based on the related literature. The limitations of the research and suggestions for future research are presented.
\end{abstract}

Keywords: Psychological counseling and guidance, career psychological counseling, reasons of preference 


\section{Giriş}

Bireyin seçtiği mesleğin eğitimine başlayıp bitirmesine kadar geçen süreç onun kariyer gelişiminin önemli bir süresini kapsar. Bireyin kendine uygun mesleği seçmesi ne kadar önemli ise, seçtiği mesleğin eğitimini isteyerek ve başarıyla sürdürmesi de o kadar önemlidir. Ancak özellikle son yıllarda yurt dışında ve ülkemizde yapılan araştırmalarda, pek çok gencin seçtiği mesleğin eğitimini sürdürürken verdikleri karardan vazgeçme eğiliminde oldukları bulunmuştur (Bacanlı, 2018; Bacanlı ve Öztemel, 2017a; Bacanlı ve Öztemel, 2017b; Gati ve Saka, 2001; Salman, 2018; Tien, 2001; Tien, 2005). Salman ve Kan (2018) psikolojik danışmanlık ve rehberlik (PDR), fen bilgisi ve matematik öğretmenliği ve mühendislik fakültesi öğrencilerinin kariyer karar verme güçlüklerini karşılaştırmışlardır. Bu araştırmanın sonuçlarını, PDR bilim dalından başka bir alana geçmek veya kariyer karar verme güçlüğüyle başa çıkabilmek için kariyer psikolojik danışma yardımı almak isteyen öğrencilerle yapılan mesleki psikolojik danışma uygulamalarının sonuçları desteklemektedir. Nitekim Bacanlı ve Salman'ın (2018) araştırmasında kariyer karar verme güçlüğü sorunuyla mesleki psikolojik danışma yardımı alan danışanın PDR mesleğini yeterince tanımamasından kaynaklanan kariyer karar verme güçlüğünü daha fazla yaşadığı belirlenmiştir. Benzer şekilde Yıldız Akyol ve Bacanlı!nın(2018) araştırmasında da kariyer karar verme güçlüğü sorunuyla çözüm odaklı kariyer psikolojik danışma yardımı alan danışanın da PDR mesleğini, kendini yeterince tanımamasından kaynaklanan kariyer karar verme güçlükleri yaşadığı belirlenmiştir Bunların yanı sıra pek çok PDR birinci ve ikinci sınıf öğrencisi bu sınıflarda PDR ağırlıklı derslerden daha çok eğitim ağırlıklı dersler okuduklarından ve bu durumun kendilerinde kariyer kararsızlı̆̆ına yol açtığından yakınmaktadırlar. Hatta bu PDR öğrencileri başka bir alana geçme sorunu yaşadıklarından da yakınmaktadırlar. Aslan, Koç ve Büyüksevindik'in (2018) PDR birinci sınıf öğrencilerinin PDR programından beklentilerini araştırdıkları araştırmanın sonuçları PDR birinci ve ikinci sınıf öğrencileri arasında yaygın olan bu yakınmaları desteklemektedir. Çünkü bu araştırmada, katılımcılar PDR lisans programında birinci ve ikinci sınıfta daha çok öğretmenlik mesleğiyle ve eğitimle ilgili derslerin ve PDR bilim dalıyla ilgili teorik ve uygulamalı derslerin az olduğundan yakınmışlardır. Bu öğrenciler birinci sınıftan itibaren PDR bilim dalıyla ilgili teorik ve uygulamalı derslere öğretmenlik mesleğiyle ve eğitimle ilgili dersler den 
daha çok yer yer verilmesini istediklerini belirtmişlerdir. Kısacası, bu bulgular da araştırmaya katılan PDR programındaki öğrencilerin bu programı yeterince tanımadan tercih ettiklerini göstermektedir.

$\mathrm{Bu}$ araştırmanın amacl, PDR programına yeni başlayan birinci sınıf öğrencilerinin PDR programını tercih nedenlerini incelemektir. Böyle bir araştırmanın sonuçlarından öncelikle liselerde ve üniversitelerde sunulacak kariyer psikolojik danışmanlığı ve rehberliği hizmetlerinin planlanması ve programlanmasında yararlanılacağı beklenilmektedir. Ayrıca, bu araştırmanın sonuçlarının okullarda PDR hizmetlerinin güçlendirilmesi amaçlı gelecekte yapılacak teorik ve uygulamalı araştırmalara ve politika geliştirme çalışmalarına da doğurgular sunacağı düşünülmektedir.

\section{Yöntem}

\section{Araştırmanın Modeli}

Araştırma, nitel araştırma yöntemine dayalı olarak yürütülmüştür. Araştırma deseni olarak ise fenomenoloji (olgubilim) kullanılmıştır. Fenomonoloji (olgubilim), farkında olunan ancak derinlemesine, ayrıntılı bir anlayışa sahip olunmayan olguları inceleyen ve bu olguları yaşayan, bu olguyu dişa vurabilecek veya yansitabilecek bireyleri araştırmayı amaçlayan nitel araştırma desenidir (Yıldırım ve Şimşek, 2018; Seggie ve Bayyurt, 2015). Bu araştırmada ele alınan olgu, PDR birinci sınıf öğrencilerinin üniversite tercih dönemi yaşantılarıdır.

\section{Çalışma Grubu}

Çalışma grubu, amaçlı örnekleme türlerinden ölçüt örnekleme yöntemi kullanılarak oluşturulmuştur. Ölçüt örnekleme, araştırmanın amacına uygun olarak önceden belirlenen bir dizi kriteri sağlayan katılımcılarıdan oluşturulan örnekleme yöntemidir (Yıldırım ve Şimşek, 2018). Bu araştırmanın amacı, PDR programına yeni başlayan birinci sınıf öğrencilerinin PDR programını tercih nedenlerini incelemektir. PDR programını tanıtan oryantasyon çalışmaları (PDR'deki mevcut derslerin içerikleri, psikolojik danışmanlık mesleğinin istihdam alanları gibi tanıtım bilgileri) tercih nedenlerini etkileyeceği için, bu araştırmanın katılımclarının üniversitelerin açıldığı ilk iki hafta 
içinde PDR ana bilim dalının tanıtımıyla ilgili oryantasyon çalışmalarına katılmayan öğrencilerden oluşturulması ölçüt olarak alınmıştır. Bu ölçüte göre araştırmanın çalışma grubu, Türkiye'deki Muğla Sıtkı Koçman Üniversitesi, Necmettin Erbakan Üniversitesi, Alanya Alaaddin Keykubad Üniversitesi, Ahi Evran Üniversitesi, Fatih Sultan Mehmet üniversitesi, Dokuz Eylül üniversitesi, Erciyes Üniversitesi, Anadolu üniversitesi, Mersin üniversitesi, Recep Tayyip Erdoğan üniversitesi olmak üzere 10 farklı üniversitede PDR Anabilim Dalı'nda lisans öğrenimine yeni başlayan ve üniversitesinde PDR programının tanıtımıyla ilgili oryantasyon çalışmasına katılmayan 200 öğrenciden oluşmaktadır. Araştırma verileri toplamak için önce adları verilen üniversitelerin PDR ana bilim dallarına yeni başlayacak öğrencilerin akademik danışmanlarıyla görüşülmüştür. Bu akademik danışmanlar aracılığıyla öğrencilere ulaşılmıştır. Araştırmanın katılımcılarından veriler, araştırmaya çevrimiçi olarak katılmaya gönüllü öğrencilerden toplanmıştır.

Araştırma grubundaki PDR programına yeni başlayan öğrencilerin üniversitelerine göre sayıları ve yüzdelikleri Tablo 1'de sunulmuştur.

Tablo 1. Araştırmaya katılan PDR öğrencilerinin üniversitelere göre sayı ve yüzdeleri

\begin{tabular}{lll}
\hline Üniversite & Öğrenci Sayısı & $\mathbf{\%}$ \\
\hline Alanya Alaaddin Keykubad Üniversitesi & 25 & 12,5 \\
\hline Muğla Sttkı Koçman Üniversitesi & 25 & 12,5 \\
\hline Necmettin Erbakan Üniversitesi & 24 & 12 \\
\hline Recep Tayyip Erdoğan Üniversitesi & 24 & 12 \\
\hline Ahi Evran Üniversitesi & 22 & 11 \\
\hline Erciyes Üniversitesi & 22 & 11 \\
\hline Fatih Sultan Mehmet Üniversitesi & 22 & 11 \\
\hline Mersin Üniversitesi & 22 & 11 \\
\hline Dokuz Eylül Üniversitesi & 7 & 3,5 \\
\hline Anadolu Üniversitesi & 7 & 3,5 \\
\hline
\end{tabular}

Tablo 1 incelendiğinde; katılımcıların 25'i $(\% 12,5)$ Alanya Alaaddin Keykubad Üniversitesi, 25'i (\%12,5) Muğla Sttkı Koçman Üniversitesi, 24' ü (\%12) Necmettin Erbakan Üniversitesi, 24'ü (\%12) Recep Tayyip Erdoğan Üniversitesi, 22'si (\%11) Ahi Evran Üniversitesi, 22'si (\%11) Erciyes Üniversitesi, 22'si (\%11) Fatih Sultan Mehmet Üniversitesi, 22'si (\%11) Mersin Ünievrsitesi, 7'si (\%3,5) Dokuz Eylül Üniversitesi ve 7'si (\%3,5) Anadolu Üniversitesi PDR programına yeni başlayan öğrencilerinden oluştuğu görülmektedir. 


\section{Veri Toplama Araci}

Araştırmada verileri toplamak için, araştırmaçlar tarafından 8'i açık uçlu ve 2'si kapalı uçlu toplam 10 sorudan oluşan soru formu geliştirilmiştir. Bu form, PDR alanında uzman ve araştırmanın konusuna hâkim 2 öğretim elemanına uzman görüşü için sunulmuştur. Bu görüşlerin sonucunda soru formunun son hali oluşturulmuştur. Soru Formu'nda yer alan sorular aşağıda sunulmuştur.

1. “Okullarda görevli psikolojik danışmanın hangi işleri yaptıkları hakkındaki bildiklerinizi kısaca yazar mısınız?"

2. "Psikolojik danışmanlar okullar dışında nerelerde çalışmaktadırlar? Adlarını yazınız."

3. "Rehber öğretmen kime denir?"

4. "Psikolojik danışman kime denir?"

5. "PDR lisans programı üniversite tercihinizde kaçıncı sırada yer alıyordu?"

6. "PDR tercihinizden önce hangi programları tercih etmiştiniz?"

7. "PDR alanını seçmeden önce bu alan hakkında bilgi edindiniz mi?"

8. "Üniversiteye giriş tercihlerinizi yaparken kimlerden ya da nerelerden yardım aldınız? Sırayalarak yazınız."

9. “-PDR alanını seçmenizi aileniz destekledi mi?"

10. "PDR alanını seçmenizin nedenlerini en önemliden daha az önemli olana doğru sıralayarak yazar mısınız?"

\section{Veri Toplama Süreci}

Araştırma verileri, Türkiye' deki 10 üniversitenin Eğitim Fakültelerinde PDR ana bilim dallarında 2017-2018 öğretim yılı güz döneminin ilk iki haftasında öğretime yeni başlayan birinci sınıf öğrencilerinden toplanmıştır. Araştırmacılar veri toplama aracının çevrimiçi formunu oluşturmuşlar ve bu form üniversitedeki akademik danışmanlar aracılığıyla araştırmaya katılmaya gönüllü öğrencilerin e-maillerine gönderilerek katılımları sağlanmıştır.

\section{Verilerin Analizi}

Veriler içerik analizi kullanılarak analiz edilmiştir. Yıldırım ve Şimşek'e (2018) göre içerik analizi, içerik ve bağlam olarak birbirine benzeyen verileri, 
belirli kavram ve temalar altında toplayarak bunları anlaşlır bir şekilde düzenlemek ve yorumlamaktır. İçerik analizi sonucunda elde edilen bulgular frekans ve yüzdelik gibi sayısal değerlere dönüştürülmüştür. Araştırmacılar tarafından yapılan kodlama işleminin güvenirliğini ölçmek amacıyla Miles ve Huberman'ın (1994) belirttiği, Görüş Birliği / (Görüş Ayrılığ 1 + Görüş Birliği) x 100 formülüne göre kodlayıcılar arası güvenirlik değerinin \%84 olduğu tespit edilmiştir. Miles ve Huberman'a (1994) göre bu değerin en az \%80 olması gerekmektedir. Buradan hareketle elde edilen kodlayıcılar arası güvenirlik değerinin yeterli olduğu söylenebilir.

\section{Geçerlik ve Güvenirlik}

Nitel araştırmalarda geçerlik ve güvenirlik çalışmaları, nicel araştırmalardan farklı olarak Erlandson, Harris, Skipper ve Allen'e (1993) göre (a)inandırıcılık, (b)aktarılabilirlik, (c)tutarlık ve (d)teyit edilebilirlik başlıklarında incelenmektedir. Aşağıda bu araştırmanın geçerlik ve güvenirliği için yapılan çalışmalar verilmiştir.

İnandırıcılı: Araştırma süreci ve sonuçlarının geçerliğine ilişkin kanıtları ifade etmektedir (Creswell, 2014). İnandırıcılığı sağlamak için Erlandson ve diğ. (1993) tarafından önerilen stratejilerden çeşitleme ve uzman incelemesi kullanılmıştır. Çeşitleme stratejisiyle Tablo 1'de görüldüğü üzere Türkiye'deki 10 farklı üniversitenin PDR anabilim dallarındaki birinci sınıf öğrencilerine ulaşılmış ve araştırmada incelenen tercih süreci olgusu için farklı deneyimler ve farklı bakış açıları elde edilmiştir. Ayrıca araştırmada uzman incelemesi stratejisiyle tasarım, uygulama, değerlendirme ve raporlaştırma süreçlerinde PDR alanında uzman ve araştırmanın konusuna hâkim 2 öğretim elemanının görüşlerinden yararlanılmıştır.

Aktarnlabilirlik: Araştırma sonuçlarının genellenebilirliğini ifade etmektedir (Yıldırım ve Şimşek,2018). Ancak sonuçların genellenebilirliği, nitel araştırmalarda nicel araştırmalardaki gibi evrene genellenebilirlikle ilgili değil benzer ortamlara uygulanabilirlikle ilgilidir (Creswell, 2014). Erlandson ve diğ. (1993) tarafından aktarılabilirliğin sağlanmasında ayrıntılı betimleme ve amaçlı örnekleme stratejileri önerilmektedir. Araştırmada tesadüfi olarak seçilen katılımcıların ifadelerine doğrudan yer verilerek ayrıntılı betimleme 
stratejisi; araştırmanın amacına uygun verilein elde edilmesi için amaçlı örnekleme stratejisi kullanılarak oryantasyon programına henüz katılmamış PDR programına yeni başlayan öğrencilere ulaşılmıştır

Tutarlık: Nitel araştırmalarda tutarlılık, mevcut değişkenliği araştırmaya yansıtabilmek olarak görülmektedir (Yıldırım ve Şimşek,2018). Erlandson ve diğ. (1993) tutarlığı sağlayabilmek için tutarlık incelemesi stratejisini önermektedir. Tutarlık incelemesi stratejisi ise uzman bir araştırmacının "dışarıdan bir göz" olarak araştırma sürecinin tutarlı olarak yürütülüp yürütülmediğini incelemesidir (Lincoln ve Guba, 1985). Araştırmada PDR alanında uzman ve konuya hâkim iki öğretim elemanından destek alınarak araştırma sürecine ilişkin dönütler alınmıştır. Ayrıca araştırmada Miles ve Huberman (1994) tarafından önerilen kodlayıcılar arası güvenirlik düzeyine bakılmış ve kodlayıcılar arasında yeterli güvenirliğin olduğu sonucuna ulaşılmıştır.

Teyit Edilebilirlik: Teyit edilebilirliğin sağlanması için Erlandson ve diğ. (1993) tarafından teyit incelemesi stratejisi önerilmektedir. Bu stratejiye göre araştırmanın ham verileri ile ulaşılan sonuçların dışarıdan bir uzmanın incelemesi için saklanması gerekmektedir. Bu nedenle araştırmada gerektiğinde teyit edilebilirliği sağlamak için elde edilen ham veriler, veri toplama araçları ve analiz sonuçları saklanmaktadır.

\section{Bulgular}

Bu bölümde araştırmanın verilerine uygulanan içerik analizi sonuçlarında ortaya çkan bulgular araştırmanın soru sırasına göre sunulmuştur. Bulgular sunulurken araştırmanın her sorusuna katılımcıların doğrudan verdikleri cevaplardan rastgele seçilerek örnek katılımcı ifadeleri verilmiştir. Katılımcı ifadelerine yer verilirken ifadenin kaçıncı sıradaki katılımcıya ait olduğu belirtmek için katılımclar kodlanmıştır (örnek: K16 gibi).

“Okullarda Görevli Psikolojik Danışmanın Hangi İşleri Yaptıklan Hakkındaki Bildiklerinizi Kısaca Yazar Mısınız?"Sorusuna İlişkin Bulgular

“Okullarda görevli rehber öğretmenin (psikolojik danışmanın) hangi işleri yaptıkları hakkındaki bildiklerinizi kısaca yazar mısınız?" sorusuna verilen cevaplara uygulanan içerik analizi sonuçları Tablo 2'de sunulmuştur. 
Tablo 2. Okullarda görevli psikolojik danışmanlarn hangi işleri yaptıklarına ilişkin bulgular

\begin{tabular}{lll}
\hline Kategoriler & $\mathbf{f}$ & $\mathbf{\%}$ \\
\hline Psikolojik destek olma & 67 & 21,2 \\
\hline Öğrenci sorunlarını çözme & 64 & 20,2 \\
\hline Verimli ders çalışma becerileri kazandırma & 54 & 17 \\
\hline Yönlendirme & 29 & 9,2 \\
\hline Danışmanlık yapma & 27 & 8,5 \\
\hline Bilgi verme & 24 & 7,5 \\
\hline Kariyer planlama & 24 & 7,5 \\
\hline Seminerler verme & 16 & 5 \\
\hline Öğrencinin kişilerarası ilişkilerini düzenleme & 10 & 3,1 \\
\hline Bilmiyorum & 1 & 0,8 \\
\hline
\end{tabular}

Tablo 2 incelendiğinde, psikolojik danışmanların görevlerinin sırayla psikolojik destek olma ( $\mathrm{f}=67, \% 21,2)$, öğrenci sorunlarını çözme ( $\mathrm{f}=64, \% 20,2)$, verimli ders çalışma becerileri kazandırma ( $\mathrm{f}=54, \% 17)$, yönlendirme ( $\mathrm{f}=29$, $\% 9,2)$, danışmanlık yapma ( $\mathrm{f}=27, \% 8,5)$, bilgi verme $(\mathrm{f}=24, \% 7,5)$, kariyer planlama ( $\mathrm{f}=24, \% 7,5)$, seminerler verme ( $\mathrm{f}=16, \% 5)$, öğrencinin kişilerarası ilişkilerini düzenleme ( $\mathrm{f}=10, \% 3,1)$ olarak belirtildiği görülmektedir. Araştırma grubundaki $\mathrm{f}=1, \% 0,8$ öğrenci ise psikolojik danışmanların okullardaki görevlerini bilmediğini ifade etmişlerdir.

Yukarıdaki bulgulara örnek olarak K54'ün görüşlerine aşağıda yer verilmektedir:

- “Öğrencileri tanımaya çalışıp zaman geldiğinde onlarnn doğru lise ve üniversiteleri, meslekleri tercih etmeleri için sağlamak. Aynı zamanda da psikolojik olarak onlara zaman zaman destek olup motive edici ve bilgilendirici konferanslar düzenlemek."

Yukarıdaki bulgulara örnek olarak K76'nın görüşlerine aşağıda yer verilmektedir:

- “Öğrencilerin gelecek planlamasına yardımcı olmak, ders çalışmalarında düzene sahip olmaları için destek sağlamak, aile ve arkadaşlarıyla ilgili problemlerini dinleyerek imkan varsa çözüme kavuşturmak"

Yukarıdaki bulgulara örnek olarak K110'un görüşlerine aşağıda yer verilmektedir:

- "Öğrencilerin davranış bozuklukların değiştirmek ve yeni davranışlar kazandırmak onlara geleceğe dair planlarında bilgi ve birikimi ile yönlendirici 
olmak okul tercihlerinde yardımcı olmak yaşadığı durumlarda ve sorunlarinda onunla bu durum ve sorunlarla ilgili konuşmak"

\section{"Psikolojik Danışmanlar Okullar Dışında Nerelerde Çalışmaktadırlar? Adların Yazınız." Sorusuna İlişkin Bulgular}

"Psikolojik danışmanlar okullar dışında nerelerde çalışmaktadırlar? Adlarını yazınız." sorusuna verilen cevaplara uygulanan içerik analizi sonuçları Tablo 3'de sunulmuştur.

Tablo 3. Psikolojik danışmanların okullar dışında çalıştıklar yerlere ilişkin bulgular

\begin{tabular}{lll}
\hline Kategoriler & f & \% \\
\hline Adliye & 77 & 14,3 \\
\hline Özel Şirketler & 43 & 9,1 \\
\hline Rehberlik Araştırma Merkezleri & 39 & 8,2 \\
\hline Türk Silahlı Kuvvetleri & 36 & 7,6 \\
\hline Hastaneler & 34 & 7,2 \\
\hline Rehabilitasyon Merkezleri & 34 & 7,2 \\
\hline Özel Psikolojik Danışma Merkezleri & 29 & 6 \\
\hline Aile ve Sosyal Politikalar Bakanlı̆ı & 28 & 5,9 \\
\hline Çocuk Esirgeme Kurumları & 20 & 4,2 \\
\hline Özel Klinikler & 20 & 4,2 \\
\hline
\end{tabular}

Tablo 3 incelendiğinde, araştırma grubundaki öğrenciler psikolojik danışmanların okullar dışında sırasıyla adliye ( $\mathrm{f}=77, \% 14,3)$, özel şirketler ( $\mathrm{f}=43$, $\% 9,1)$, rehberlik araştırma merkezleri ( $\mathrm{f}=39, \% 8,2)$, Türk Silahlı Kuvvetleri $(\mathrm{f}=39, \% 8,2)$, hastaneler $(\mathrm{f}=34, \% 7,2)$, rehabilitasyon merkezleri $(\mathrm{f}=34, \% 7,2)$, özel psikolojik danışma merkezleri ( $\mathrm{f}=29, \% 6)$ ve aile-sosyal politikalar bakanlığında $(\mathrm{f}=28, \% 6)$ çalıştıklarını ifade etmişlerdir. Bunların yanı sıra Tablo 3'de öğrenciler psikolojik danışmanların hastaneler $(\mathrm{f}=34, \% 7,2)$, klinikler ( $\mathrm{f}=20$, $\% 4,2)$, sevgi evleri $(\mathrm{f}=2, \% 0,4)$ ve adli tıp kurumları $(\mathrm{f}=2, \% 0,4)$ gibi yerlerde de çalıştıklarını belirtmişlerdir.

Yukarıdaki bulgulara örnek olarak K63'ün görüşlerine aşağıda yer verilmektedir:

- "Aile mahkemelerinde, emniyette çocuk şube müdürlü̈̆̈̈nde, çocuk esirgeme kurumlarında, askeriyede, özel danışmanlık kurumlarında çalışabilirler." 
Yukarıdaki bulgulara örnek olarak K81'in görüşlerine aşağıda yer verilmektedir:

- "Rehabilitasyon merkezleri, özelhastaneler, sosyal hizmetler ve yüksek lisansla klinik psikolog olarak çalışabiliyorlar."

Yukarıdaki bulgulara örnek olarak K84'ün görüşlerine aşağıda yer verilmektedir:

- "Rehberlik araştırma merkezlerinde, adliyelerde, çocuk esirgeme kurumlarinda ve özel yerlerde çalışabilirler."

\section{“Rehber Öğretmen Kime Denir?” Sorusuna İlişkin Bulgular}

"Rehber öğretmen kime denir?" sorusuna verilen cevaplara uygulanan içerik analizi sonuçları Tablo 4'de sunulmuştur.

Tablo 4. Rehber öğretmen algısına ilişkin bulgular

\begin{tabular}{lll}
\hline Kategoriler & $\mathbf{f}$ & $\mathbf{\%}$ \\
\hline Öğrenciye yol gösteren kişi & 80 & 40,9 \\
\hline Psikolojik sorunları çözmeye yardımcı olan öğretmen & 50 & 23,8 \\
\hline Okul psikolojik danışmanı & 36 & 18,2 \\
\hline PDR mezunu & 23 & 11,6 \\
\hline Sınıf rehber öğretmeni & 3 & 1,5 \\
\hline Derslerle ilgili destek sunan öğretmen & 3 & 1,5 \\
\hline Öğrencilere her türlü yardımı yapan kişi & 2 & 1 \\
\hline Özel odası olan öğretmen & 2 & 1 \\
\hline Tercih sürecinde yardımcı olan öğretmen & 1 & 0,5 \\
\hline
\end{tabular}

Tablo 4 incelendiğinde, araştırma grubundaki öğrenciler "Rehber öğretmen kime denir?" sorusuna sırayla öğrenciye yol gösteren kişi ( $\mathrm{f}=80, \% 40,9)$, öğrencilerin psikolojik sorunlarını çözmeye yardımcı olan öğretmen ( $\mathrm{f}=50$, $\% 23,8)$, okul psikolojik danışmanı ( $\mathrm{f}=36, \% 18,2)$, PDR mezunu ( $\mathrm{f}=23, \% 11,6)$, sinıf rehber öğretmeni ( $\mathrm{f}=3, \% 1,5)$, derslerle ilgili destek sunan öğretmen ( $\mathrm{f}=3$, $\% 1,5)$, öğrencilere her türlü yardımı yapan kişi ( $\mathrm{f}=2, \% 1$ ), özel odası olan öğretmen $(\mathrm{f}=2, \% 1)$ ve tercih sürecinde yardımcı olan öğretmen $(\mathrm{f}=1, \% 0,5)$ cevabını vermişlerdir.

Yukarıdaki bulgulara örnek olarak K58' in görüşlerine aşağıda yer verilmektedir:

- "Rehberlik ve psikolojik danışmanlık bölümünden mezun olan ve öğretmen olmayı tercih eden kişidir." 
Yukarıdaki bulgulara örnek olarak K170'in görüşlerine aşağıda yer verilmektedir:

- "Adı üzerinde sanırım, yol gösteren, kişiye rehber olan kimseler olmahlar. Dert ve sıkıntıların çözümü veyahut hafifletilmesi hakkında çalısmalar yaparlar. Okulda boş boş oturmazlar. Stres yönetimi, ders çalışma teknikleri üzerine çalş̧ırlar diye düşünüyorum ben."

Yukarıdaki bulgulara örnek olarak K180'in görüşlerine aşağıda yer verilmektedir:

- “Öğrencilerin sorunları olduğunda ilk başvuracakları kapı diyebiliriz aslında yalnı öğrencilerin değil velilerin yeri geldiğinde hocalarm ve idarenin de sorunlarına yardımcı olan kişidir."

\section{“Psikolojik Danışman Kime Denir?" Sorusuna İlişkin Bulgular}

"Psikolojik danışman kime denir?" sorusuna verilen cevaplara uygulanan içerik analizi sonuçları Tablo 5'de sunulmuştur.

Tablo 5. Psikolojik danışman algısına ilişkin bulgular

\begin{tabular}{lll}
\hline Kategoriler & f & \% \\
\hline Psikolojik sorunların çözümünde yardımcı olan & 91 & 42,8 \\
\hline PDR mezunu & 37 & 17,4 \\
\hline Okul dışındaki kurumlarda çalışan PDR mezunu & 25 & 12,3 \\
\hline Psikoloji mezunu & 20 & 9,3 \\
\hline Yol gösteren kişi & 18 & 8,4 \\
\hline Rehberlik öğretmeni & 7 & 3,3 \\
\hline Yetişkinlerin sorunlarıyla çalışan kişi & 5 & 2,3 \\
\hline Psikolojik danışma yapan kişi & 5 & 2,3 \\
\hline İnsan davranışlarını inceleyen kişi & 2 & 0,9 \\
\hline
\end{tabular}

Tablo 5 incelendiğinde, araştırma grubundaki öğrencilerin “ Psikolojik danışman kime denir?" sorusuna sırayla psikolojik sorunların çözümünde yardımcı olan ( $\mathrm{f}=91, \% 42,8)$, PDR mezunu ( $\mathrm{f}=37, \% 17,4)$, okul dışındaki kurumlarda çalışan PDR mezunu ( $\mathrm{f}=25, \% 12,3)$, psikoloji mezunu ( $\mathrm{f}=20, \% 9,3)$, yol gösteren kişi $(\mathrm{f}=18, \% 8,4)$, rehberlik öğretmeni $(\mathrm{f}=7, \% 3,3)$ ve yetişkinlerin sorunlarıyla çalışan kişi $(\mathrm{f}=5, \% 2,3)$ olarak görülmektedir. Bu bulgulara ek olarak psikolojik danışmanın psikolojik danışma yapan kişi ( $\mathrm{f}=5, \% 2,3)$, insan davranışlarını inceleyen kişi $(\mathrm{f}=2, \% 0,9)$, kendini gerçekleştiren kişi $(\mathrm{f}=1, \% 0,5)$ 
olarak cevap vermişlerdir. Bir öğrenci ise bilmiyorum ( $\mathrm{f}=1, \% 0,5)$ cevabını vermiştir.

Yukarıdaki bulgulara örnek olarak K66'nın görüşlerine aşağıda yer verilmektedir:

- "Her türlü problemimizde danışabileceğimiz, şarttsız kayıtsız ve yargılamadan destek olan yol gösteren ve bize farklı bakış açıları kazandıran kişiye denir."

Yukarıdaki bulgulara örnek olarak K42'nin görüşlerine aşağıda yer verilmektedir:

- "Eğitim kurumlarıyla sinırlamadan belli durumlardaki her insana yardım edebilen yaşam koçu da denilen mesleği yapan kişi."

Yukarıdaki bulgulara örnek olarak K61'in görüşlerine aşağıda yer verilmektedir:

- "Insanlarm sorunlarnyla ilgilenen, onlara çare bulmaya çalışan, toplumdan itilmiş insanlan topluma yeniden kazandırmaya çalşan ve bunları kendine meslek edinmiş insanlara denir."

\section{“PDR Lisans Programı Üniversite Tercihinizde Kaçıncı Sırada Yer Alıyordu?" Sorusuna İlişkin Bulgular}

"Rehberlik ve Psikolojik Danışmanlık (PDR) lisans programı üniversite tercihinizde kaçıncı sırada yer alıyordu?" sorusuna verilen cevaplara uygulanan içerik analizi sonuçları Tablo 6'da sunulmuştur.

Tablo 6. PDR programının tercih listesinde kaçıncı sırada olduğuna ilişkin bulgular

\begin{tabular}{lll}
\hline Kategoriler & f & \% \\
\hline Birinci & 63 & 31,5 \\
\hline İkinci & 31 & 15,5 \\
\hline Üçüncü & 19 & 9,5 \\
\hline Dördüncü & 17 & 8,5 \\
\hline Beşinci & 12 & 6 \\
\hline Altıncı & 11 & 5,5 \\
\hline Dokuzuncu & 8 & 4 \\
\hline On Birinci & 5 & 2,5 \\
\hline On İkinci & 5 & 2,5 \\
\hline
\end{tabular}


Tablo 6'ya bakıldığında araştırmaya katılan PDR Anabilim Dalı öğrencilerinin üniversite tercihlerinde PDR programını kaçıncı tercihlerine yazdıklarına ilişkin olarak elde edilen bulgulara göre çoğunlukla birinci $(\mathrm{f}=63, \% 31,5)$, ikinci ( $\mathrm{f}=31, \% 15,5)$, üçüncü ( $\mathrm{f}=19, \% 9,5)$, dördüncü $(\mathrm{f}=17, \% 8,5)$, beşinci $(\mathrm{f}=12$, $\%$, altınc ( $(\mathrm{f}=11, \% 5,5)$ ve dokuzuncu $(\mathrm{f}=8, \% 4)$ tercihlerine yazdıkları görülmektedir.

"PDR tercihinizden önce hangi programlarn tercih etmiştiniz?" sorusuna ilişkin bulgular

"PDR tercihinizden önce hangi programları tercih etmiştiniz?" Sorusuna verilen cevaplara uygulanan içerik analizi sonuçları Tablo 7'de sunulmuştur.

Tablo 7. PDR' den önce hangi programlarn tercih edildiğine ilişkin bulgular

\begin{tabular}{lll}
\hline Kategoriler & f & \% \\
\hline İk ve tüm tercihleri PDR & 95 & 38,6 \\
\hline Hukuk & 88 & 35,7 \\
\hline Psikoloji & 53 & 22,1 \\
\hline Siyaset bilimi & 2 & 0,8 \\
\hline Sosyal hizmetler & 2 & 0,8 \\
\hline Mimarlık & 2 & 0,8 \\
\hline Fizyoterapi & 1 & 0,4 \\
\hline Sosyoloji & 1 & 0,4 \\
\hline Uluslararası ilişkiler & 1 & 0,4 \\
\hline Özel eğitim öğretmenliği & 1 & 0,4 \\
\hline
\end{tabular}

Tablo 7 incelendiğinde, araştırma grubundaki öğrencilerin \%38,6's1 (f=95) ilk ve tüm tercihlerinin PDR programı olduğunu belirtmişlerdir. Öğrencilerin ilk tercihlerine sirasiyla \%35,7'si (f=88) hukuk, \%22,1'i (f=53) psikoloji, \%0,8' $\mathrm{i}$ ( $\mathrm{f}=2$ ) siyaset bilimi, $\% 0,8^{\prime} \mathrm{i}(\mathrm{f}=2)$ sosyal hizmetler, $\% 0,8^{\prime} \mathrm{i}(\mathrm{f}=2)$ mimarlık, fizyoterapi ( $\mathrm{f}=1, \% 0,4)$, sosyoloji $(\mathrm{f}=1, \% 0,4)$, uluslararası ilişkiler $(\mathrm{f}=1, \% 0,4)$ ve özel eğitim öğretmenliği ( $\mathrm{f}=1, \% 0,4)$ gibi programları PDR programlarından önce tercih ettikleri görülmektedir.

\section{“PDR Alanın Tercih Etmeden Önce Hakkında Bilgi Edindiniz Mi?” Sorusuna İlişkin Bulgular}

"PDR alanın tercih etmeden önce hakkında bilgi edindiniz mi?" sorusuna verilen cevaplara uygulanan içerik analizi sonuçları Tablo 8' de sunulmuştur. 
Tablo 8. PDR alanın tercih etmeden önce hakkında bilgi edinmeye ilişkin bulgular

\begin{tabular}{lll}
\hline Kategoriler & f & \% \\
\hline Evet & 186 & 93 \\
\hline Hayır & 14 & 7 \\
\hline
\end{tabular}

Tablo 8'e bakıldığında araştırma grubundaki öğrencilerin PDR programını tercih etmeden önce \%93'ünün ( $\mathrm{f}=186$ ) programa ilişkin bilgi topladığı, $\% 7^{\prime} \operatorname{sinin}$ ise $(\mathrm{f}=14)$ bilgi toplamadığı görülmektedir.

\section{"Üniversiteye Giriş Tercihlerinizi Yaparken Kimlerden Ya Da Nerelerden Yardım Aldınız? Strayalarak Yazını." Sorusuna İlişkin Bulgular}

"Üniversiteye giriş tercihlerinizi yaparken kimlerden ya da nerelerden yardım aldınız? Sırayalarak yazınız." sorusuna verilen cevaplara uygulanan içerik analizi sonuçları Tablo 9'da gösterilmektedir.

Tablo 9. Üniversiteye giriş tercihlerini yaparken kimlerden ya da nerelerden yardım alındiğına ilişkin bulgular

\begin{tabular}{lll}
\hline Kategoriler & f & \% \\
\hline Okul psikolojik danışmanları & 91 & 28,1 \\
\hline Aile üyeleri & 91 & 28,1 \\
\hline Branş öğretmenleri & 54 & 17,2 \\
\hline İnternet & 32 & 9,9 \\
\hline Yardım almadım & 18 & 5,5 \\
\hline Arkadaş & 11 & 3,4 \\
\hline PDR öğrencileri & 7 & 2,1 \\
\hline Mezun öğrenciler & 6 & 1,8 \\
\hline Akademisyenler & 5 & 1,5 \\
\hline Tercih stantları & 4 & 1,2 \\
\hline
\end{tabular}

Tablo 9'a bakıldığında, araştırma grubundaki öğrencilerin üniversite tercihlerini yaparken okul psikolojik danışmanlarından ( $\mathrm{f}=91, \% 28,1)$, aile üyelerinden ( $\mathrm{f}=91, \% 28,1)$, branş öğretmenlerinden ( $\mathrm{f}=54, \% 17,2)$, internetten ( $\mathrm{f}=32, \% 9,9)$, arkadaşlardan ( $\mathrm{f}=11, \% 3,4)$, PDR öğrencilerinden ( $\mathrm{f}=7, \% 2,1)$, mezun öğrencilerden ( $\mathrm{f}=6, \% 1,8)$, akademisyenlerden $(\mathrm{f}=5, \% 1,5)$, tercih stantlarından ( $\mathrm{f}=4, \% 1,2)$, RAM psikolojik danışmanlarından ( $\mathrm{f}=3, \% 0,9)$, televizyon programlarından $(\mathrm{f}=1, \% 0,3)$ yardım aldıkları görülmektedir. Araştırma grubundaki öğrencilerin $\% 5,5^{\prime} \mathrm{i}$ ( $\mathrm{f}=18$ ) ise üniversite tercihi yaparken herhangi bir yardım almadığını belirtmiştir. 
Yukarıdaki bulgulara örnek olarak K33'ün görüşlerine aşağıda yer verilmektedir:

- “Eğitim gördüğ̈̈m okuldaki rehberlik öğretmenimden. Ailemden. Ailemde eğitimci olarak çalışan kişilerden ve rehberlik ve psikolojik danışmanlik okuyan arkadaşlarımdan yardım almışım."

Yukarıdaki bulgulara örnek olarak K70'in görüşlerine aşağıda yer verilmektedir:

- "Rehber öğretmenimden, babam ve annemden, beni en iyi taniyan öğretmenimden, internetten, bu bölümü okuyan kişilerden ve en yakın arkadaşımdan destek aldim."

Yukarıdaki bulgulara örnek olarak K120'nin görüşlerine aşağıda yer verilmektedir:

- "Internetten araştırma yaptım, rehber öğretmenden yardım aldım ve aileme danıştım."

\section{“PDR Alanın Seçmenizi Aileniz Destekledi Mi?"Sorusuna İlişkin Bulgular}

"PDR alanını seçmenizi aileniz destekledi mi?" sorusuna verilen cevaplara uygulanan içerik analizi sonuçları Tablo 10'da sunulmuştur.

Tablo 10. PDR alanını seçmede ailenin desteğinin olup olmadığına ilişkin bulgular

\begin{tabular}{lll}
\hline Kategoriler & f & \% \\
\hline Evet & 186 & 93 \\
\hline Hayır & 14 & 7 \\
\hline
\end{tabular}

Tablo 10'a bakıldığında, araştırma grubundaki öğrencilerin \%93'ü ( $\mathrm{f}=186)$ PDR programinı tercih etmelerini ailelerinin desteklediklerini, \% $\%$ 'sinin ( $\mathrm{f}=14$ ) ise ailelerinin desteklemediğini belirtmişlerdir.

\section{"PDR Alanını Seçmenizin Nedenlerini En Önemliden Daha Az Önemli Olana Doğru Sıralayarak Yazar Misını??" Sorusuna İlişkin Bulgular}

"PDR alanını seçmenizin nedenlerini en önemliden daha az önemli olana doğru sıralayarak yazar mısınız?" sorusuna verilen cevaplara uygulanan içerik analizi sonuçları Tablo 11'de sunulmuştur. 
Tablo 11. PDR alanını seçmenizin nedenlerine ilişkin bulgular

\begin{tabular}{lll}
\hline Kategoriler & f & \% \\
\hline İnsanlara yardım etmekten hoşlanma & 74 & 20,4 \\
\hline Psikolojiye ilgi duyma & 60 & 16,6 \\
\hline Kişiliğe uygunluk & 53 & 14,6 \\
\hline Kolay istihdam imkânı & 38 & 10,5 \\
\hline Puan yetersizliği & 25 & 6,8 \\
\hline Kişisel gelişim & 20 & 5,5 \\
\hline Gelecekteki ideallere uygunluk & 18 & 4,9 \\
\hline Popülerlik & 16 & 4,4 \\
\hline Çalış̧ma koşullarının rahatlığı & 15 & 4,1 \\
\hline Aile isteği & 12 & 3,3 \\
\hline Çalışma alanın genişliği & 13 & 3,6 \\
\hline Öğretmen olmayı istemek & 8 & 2,2 \\
\hline Eğitiminin kolaylı̆̆ & 4 & 1,1 \\
\hline Maddi kazançlarının iyi olması & 3 & 0,8 \\
\hline Okulundaki psikolojik danışmanın model alınması & 2 & 0,5 \\
\hline
\end{tabular}

Tablo 11 incelendiğinde, araştırma grubundaki öğrencilerin PDR programinı tercih nedeni olarak sırasıyla insanlara yardım etmekten hoşlanma $(\mathrm{f}=74, \% 20,4)$, psikolojiye olan ilgi $(\mathrm{f}=60, \% 16,6)$, kişiliğe uygunluk ( $\mathrm{f}=53$, \%14,6), kolay istihdam imkân ( $\mathrm{f}=38, \% 10,5)$, kişisel gelişim ( $\mathrm{f}=20, \% 5,5)$, gelecekteki ideallere uygunluk ( $\mathrm{f}=18, \% 4,9)$, popülerlik ( $\mathrm{f}=16, \% 4,4)$, puan yetersizliği $(\mathrm{f}=16, \% 4,4)$, çalışma koşullarının rahatlığı ( $\mathrm{f}=15, \% 4,1)$, aile isteği ( $\mathrm{f}=12$, $\% 3,3)$ ve çalışma alanının genişliğini $(\mathrm{f}=13, \% 3,6)$ belirtmişlerdir. Araştırma grubundaki öğrencilerin $\% 2,2^{\prime}$ si ( $\mathrm{f}=8$ ) öğretmen olmak istedikleri, \%1, $1^{\prime} \mathrm{i}(\mathrm{f}=4$ ) eğitiminin kolay olduğunu, \%0,8'i ( $\mathrm{f}=3)$ maddi kazançlarının iyi olduğunu, $\% 0,5^{\prime} i(f=2)$ okulundaki psikolojik danışmanı model aldıklarını belirtmişlerdir.

Yukarıdaki bulgulara örnek olarak K66' in görüşlerine aşağıda yer verilmektedir:

- “Insanlar dinlemeyi çözüm yollar önermeyi ve onlara farklı açılardan bakarak problemlerini aşabileceklerini göstermeyi seviyorum. Karakter ve yeteneklerime uygun olduğunu düşündüğ̈̈̈m için tercih ettim."

Yukarıdaki bulgulara örnek olarak K93'ün görüşlerine aşağıda yer verilmektedir:

- Açıkta kalma olasılığının öteki alanlara göre daha az olduğu için, stralamamdan dolayı, çalışma alaminın geniş olması, seçebileceğim çok fazla olanağın olmaması nedeniyle seçtim." 
Yukarıdaki bulgulara örnek olarak K155' in görüşlerine aşağıda yer verilmektedir:

- "Insanlara yardim etmeyi seviyorum.Bölüm aktif ve uygulamalar içeriyor. Diğer öğretmenliklere göre daha rahat ve atamaları çok da zor değil."

\section{Tartışma ve Sonuç}

Bu araştırmada, PDR lisans programına yeni başlayan birinci sınıf öğrencilerinin PDR programını tercih nedenleri araştırılmıştır. Çalışma grubundaki öğrenciler okullarındaki psikolojik danışmanların görevlerinin neler olduğu sorusuna; sırasıyla psikolojik destek olma, öğrenci sorunlarını çözme, verimli ders çalışma becerileri kazandırma, yönlendirme ve bilgi verme cevaplarını vermişlerdir. Bu bulgular alan yazındaki önceki benzeri araştırmaların sonuçlarıyla benzerlik göstermektedir. Şöyle ki; Meşeci, Dinçer ve Çırakoğlu (2006) ortaokul ve lise öğrencilerinin psikolojik danışmanı daha çok psikolojik yardım veren, olumsuz davranışları düzeltmeye yardımcı olan ve verimli ders çalışma, zaman yönetimi konularında bilgi veren kişiler olarak gördüklerini belirlemişlerdir. Eren- Gümüş (2018) okul yöneticilerinin, psikolojik danışmanların rol ve görevlerine ilişkin algılarını incelediği araştırmasında, okul yöneticilerinin psikolojik danışmanı öğrenci problemlerini ve gereksinimlerini tanımlama ve çözmede okul yönetimine yardımcı olan kişi olarak algıladıklarını bulmuştur. Korkut Owen ve W. Owen'in (2008) araştırmasında da okul yöneticilerinin psikolojik danışmanların rol ve işlevlerini öğrencilerin iyilik hallerini artırma olarak algıladıklarını belirlemişlerdir. Karataş ve Şahin-Baltacı'nın (2013) çalışmasında ise, lise öğrencileri, psikolojik danışmanların ve PDR hizmetlerinin işlevlerini sorun çözme, yardım etme, yöneltme, yol gösterme ve bilgi verme olarak sıralamışlardır. Dolayısıyla, bu önceki araştırmaların bulguları bu sunulan araştırmanın bulgularıyla karşılaştırıldığında; bu araştırmaya katılan PDR programına yeni başlayan öğrencilerin de psikolojik danışmanların görevlerini alanyazındaki önceki araştırmalarda tanımlananlara oldukça benzer olarak tanımladıkları söylenebilir. Ancak hem bu sunulan araştırmanın bulgularında hem de yukarda sözü edilen alanyazındaki önceki araştırmaların bulgularında yer alan psikolojik danışmanın "problem çözücü" olduğuna ilişkin görevi, psikolojik danışmanların rol ve görevlerini tanımlayan bilimsel görüşlerle bağdaşmamaktadır. 
Çünkü ilgili literatürde, psikolojik danışma ve rehberlik hizmetinin asıl amacıbireylerin kişiliklerini daha iyi tanımalarıve problemlerine çözüm yolları bulmaları için onların kendi kendilerine yeterli bir duruma gelmelerini sağlamaktır (Kepçeoğlu, 1994). Kuzgun'a (2008) göre ise, psikolojik danışma ve rehberlik hizmetleri, bireye sorunlarını çözmesi ve içinde yaşadığı toplumun özgür ve sorumlu bir üyesi olabilmesi için sunulan bir yardımdır. Bu hizmeleri de üniversitelerin PDR programlarından mezun profesyonel meslek mensupları yani psikolojik danışmanlar yapabilirler. Dolayısıyla, psikolojik danışmanların görevleri, bireylerin problemlerini onlar adına çözmek değildir, bireylerin problemlerini kendi kendilerine çözebilmeleri için gereken bilgi ve becerileri onlara kazandırmaya yardımcı olmaktır. Kısacası bu araştırmanın birinci sorusuna ilişkin bu bulgu, bir yandan araştırma grubundaki öğrencilerin okullardaki psikolojik danışmanların görevleri hakkında yeterli bilgiye sahip olmadıklarını düşündürmektedir. Diğer yandan bu bulgu, okullardaki psikolojik danışmanların, okullarda psikolojik danışma ve rehberlik hizmetlerini yeterince tanıtmadıklarını da akla getirmektedir. Bu bulguya dayanarak okul psikolojik danışmanlarının öncelikle okullarda PDR hizmetlerindeki rol ve işlevlerini tanıtmaya yönelik çalışmalara öncelik vermeleri gerektiğinden söz edilebilir.

Araştırmaya katılan öğrenciler, psikolojik danışmanların okullar dışında nerelerde çalıştıkları sorusuna sırasıyla; adliye, özel şirketler, Rehberlik Araştırma Merkezleri (RAM), Türk Silahlı Kuvvetleri, hastaneler, rehabilitasyon merkezleri, özel psikolojik danışma merkezleri, Aile ve Sosyal Politikalar Bakanlığı, çocuk esirgeme kurumları, özel klinikler, emniyet, ceza evleri, huzurevleri ve üniversiteler gibi çok çeşitli kurum ve kuruluşların adlarını söylemişlerdir.Öcal'ın(2010) araştırmasındaki katılımcılar PDR programından mezun psikolojik danışmanların okullar dışında en fazla sırasıyla RAM'larda, üniversitelerde, kendine ait iş yerinde, özel rehabilitasyon merkezlerinde, MEB dışındaki diğer bakanlıklarda, özel eğitim merkezlerinde çalıştıklarını belirtmişlerdir. Zimpfer (1996) ise Amerika'daki danışman eğitimi ve danışma psikolojisi mezunlarının çalışma alanlarını belirlemeyi amaçladığı çalışmada, mezunların daha çok özel danışma merkezlerinde, ünivesitelerde ve yüksekokullarda, hastanelerde çalıştıklarını bulmuştur. Dolayısıyla bu araştırmanın bulguları önceki araştırmaların bulgularını desteklemektedir. Ancak Zimpfer'in (1996) araştırmasının katılımcıları tarafından ifade edi- 
len, psikolojik danışmanların hastanelerde ve özel kliniklerde çalışabileceklerine ilişkin görüşün Türkiye'de uygulaması henüz bulunmamaktadır. Bunun yanısıra bu araştırmaya katılan öğrenciler, PDR mezunlarının istihdam edildikleri alanlar arasında adliyelere ve özel şirketlere ilk sıralarda yer vermişlerdir. Ancak, Türkiye'de PDR mezunlarının adliyelerde ve özel şirketlerde istihdamları henüz son yıllarda yapılmaktadır. Üstelik bu alanlarda istihdamedilen psikolojik danışman sayıları da oldukça azdır. Benzer durum, Türk Silahlı Kuvvetleri, özel eğitim ve rehabilitasyon merkezleri ile Aile ve Sosyal Politikalar Bakanlığı için de geçerlidir. Kısacası bu bulgular, araştırmaya katılan öğrencilerin çoğunun öncelikle Türkiye'de PDR mezunlarına açlk mevcut istihdam alanları hakkında yeterli bilgiye sahip olmadıkların hatta bazı bilgilerinin de yanlış olduğunu ortaya koymaktadır. Bu bulgulara dayanılarak araştırmaya katılan öğrencilerin, PDR programından mezun olduklarında çalışmak için başvurabilecekleri istihdam alanları hakkında bilgi edinmelerine ihtiyaçları olduğu söylenebilir. Buna ilaveten liselerde çalışan psikolojik danışmanların psikolojik danışmanlık ve diğer mesleklerin istihdam alanlarını ve geleceklerini tanıtan kariyer psikolojik danışmanlığı ve rehberliği hizmetlerinin sunmaları gerektiği söylenebilir.

Araştırmaya katılan öğrenciler, rehber öğretmen kime denir? sorusuna s1rasıyla; öğrenciye yol gösteren kişi, öğrencilerin psikolojik sorunlarını çözmeye yardımcı olan öğretmen, okul psikolojik danışmanı, PDR mezunu, sınıf rehber öğretmeni, derslerle ilgili destek sunan öğretmen, öğrencilere her türlü yardımı yapan kişi, özel odası olan öğretmen ve tercih sürecinde yardımcı olan öğretmen cevaplarını vermişlerdir. Bu bulgular, araştırma grubundaki öğrencilerin rehber öğretmeni, daha çok okul ve öğrenci ile ilgili eğitim öğretim hizmetlerine yardımcı görevliler olarak tanımladıklarını göstermektedir. Bu bulguların okullarda rehberlik servislerinde çalışan psikolojik ıdanışmanların rehber öğretmen veya rehberlik öğretmeni ünvanlarını taşımalarını öğrencilerde öğretmen ünvanını daha çabuk ve kolay çağrıştırdığını ve bunun sonucu olarak da öğrencilerin bu ünvanları taşıyanları ders öğretmenlerine yardımcı olan öğretmen olarak tanımladıkları düşünülebilir. Böyle algılamalar ve tanımlamalar doğal olarak liselerdeki öğrencilerin hem okul PDR servislerindeki rehber öğretmen veya rehberlik öğretmeni ünvanıyla görevlendirilen psikolojik danışmanların rol ve işlevlerini hem de okul PDR hizmetlerinin amacını kolay ve çabuk anlamalarını ve bu hizmetlere yönelik olumlu tutum geliştirmelerini engelleyebilir.Üstelik rehber öğretmen ve 
rehberlik öğretmeni ünvanları okul psikolojik danışmanlarının rol ve görevlerini sınırlandırmaktadır (Özgüven, 1990). Bu durumun ise, psikolojik danışmanlık mesleğinin gelişimini engelleyici bir rol oynayacağı söylenebilir. Kısacası, okullarda çalışan PDR mezunlarının rehber öğretmen veya rehberlik öğretmeni gibi öğrenciye sadece öğretimi veya öğretmeni hatırlatan ünvanlarla değil istihdam edilmemeleri, asıl hizmetlerini hemen hatırlatan ve çağrıştıran okul psikolojik danışmanı ünvanıyla istihdam edilmeleri önerilmektedir.

Psikolojik danışmanının kim olduğuna ilişkin soruya, çalışma grubundaki öğrencilerin çoğu, psikolojik danışmanı psikolojik sorunların çözümünde yardımcı olan, PDR mezunu, okul dışındaki kurumlarda çalışan PDR mezunu, psikoloji mezunu kişi cevaplarını vermişlerdir.. Bazı katılımcılar ise,psikolojik danışmanı, yol gösteren kişi, rehberlik öğretmeni, yetişkinlerin sorunlarıyla çalışan kişi, psikolojik danışma yapan kişi ve insan davranışlarını inceleyen kişi olarak tanımlamışlardır. Ülkemizde rehber öğretmen ve psikolojik danışman unvanlarının kullanımına ilişkin halen bir karışıklık yaşansa da, "Rehber Öğretmen” unvanının, tahsis edilen kadronun adı olduğu, "Psikolojik Danışman" unvanının ise mesleki kimlik unvanı olduğu, alanda çalışanlarca benimsenmektedir (Yeşilyaprak, 2007). Özgüven (1990), psikolojik danışman unvanının daha kapsayıcı olduğunu çünkü toplumun psikolojik danışma ve rehberlik hizmetlerine duyduğu gereksinime dayalı olarak, PDR mezunlarının sadece Milli Eğitim Bakanlığı tarafından değil, Sağlık Bakanlığı, Adalet Bakanlığı, Çalışma Bakanlığı, üniversiteler, mediko sosyal merkezleri gibi diğer kamu ve özel kuruluşlar ile endüstri alanında da istihdam edildiklerini ifade etmektedir.

PDR programının tercih listesinde kaçıncı sırada yer aldığına ilişkin bulgular katılımcıların PDR programını sırasıyla birinci, ikinci, üçüncü, dördüncü, beşinci ve altıncı sırada tercih etiklerini göstermektedir. Alanyazına bakıldığında Özer ve Avcı (2015) Hacettepe, Ankara, Boğaziçi ve Başkent üniversitelerinde öğrenim gören PDR birinci sinıf öğrencileri üzerinde yaptığı araştırmada Hacettepe üniversitesindeki öğrencilerin PDR programını birinci sırada; Boğaziçi ve Ankara üniversitelerindeki öğrencilerin ise ikinci sırada tercih ettiklerini belirlemişlerdir.. Sarıkaya ve Khorshid'in (2009) araştırmasında ise, öğrencilerin üniversiteye yerleşme tercih sıralamasını yaparken 1ve 6.tercihleri arasına en çok istedikleri ve hakkında olumlu düşünce- 
lere sahip oldukları meslekleri yazdıklarını, 13-ve 18. Tercihler arasına başkalarının önerdikleri meslekleri, 19ve-24.tercihler arasına da herhangibir meslege girmek,açıta kalmamak için meslek adları yazdıklarını,çaresizlik duyguları yaşadıklarını ifade etmişlerdir.. Bu bulgularla bu sunulan araştırmanın PDR programını tercih nedenleri karşılaştırıldığında; bu araştırmaya katılan öğrencilerin çoğunluğunun PDR programını tercih listelerinde ilk üç sıraya ve istediklei içn yazdıkları söygörülmektdir.

Çalışma grubundaki katılımcıların yaklaşık üçte biri ilk ve tüm tercihlerinie PDR programını yazdıklarını belirtmişlerdir. Bu katılımcılardan diğer üçte biri ise ilk tercihlerine hukuk, bunu takiben sırasıyla psikoloji, siyaset bilimi, sosyal hizmetler, mimarlık, fizyoterapi sosyoloji, uluslararası ilişkiler ve özel eğitim öğretmenliği programlarını sonar da PDR programlarını yazdıkların belirtmişlerdir. Bu bulgular genel olarak değerlendirildiğinde; PDR'yi ilk tercihleri olarak belirtenlerin yüzdelikleri ile hukuk olarak belirtenlerin yüzdeliklerinin birbirine çok yakın olduğum dikkati çekmektedir. Bu durumun PDR ve huhuk programlarının ayn puan türünden( eşiit ağırlık) öğrenci almalarından ve bu programları tercih eden öğrencilerin benzer başarı sıralamalarına sahip olmalarından kaynaklandığı düşünülmektedir.

PDR programını tercih etmeden önce hakkında bilgi topladınız mı? sorusuna öğrencilerin \%93'ü bilgi topladığını, \%7'siise bilgi toplamadığını ifade etmiştir.. Bu bulguların Yelken'in (2008) lise öğrencilerinin \%73,4'ünün seçeceği meslekle ilgili bilgi edindiklerini,\%26,6'sının ise herhangi bir bilgi edinmediklerini belirttikleri araştırmasının bulgularına genel olarak benzediği söylenebilir.Bu iki araştırmanın bulguları genel olarak değerlendirildiğinde de üniversite tercihi yapan öğrencilerin genellikle çoğunun tercih edecekleri bölümle ilgili bilgi topladıklarıhatta bu sunulan araştırmada görüldüğü üzere öğrenciler arasında tercih edilecek meslekler hakkında bilgi toplama mesleki gelşim görevinin (Super,1990) giderek lise öğrencileri arasında üstlenildiğii söylenebilir. Ancaköğrencilerin üniversiteler, üniversitelerdeki programlar ve meslekler hakkında bilgileri hangi kaynaklardan edindikleri önemlidir. Özellikle online toplanan bilgierin güvenirliklerinin ve güncelliklerinin mutlaka incelenmsi gereklidir. Bu konuda da okullardaki psikolojik danışmanların sorumluluklar almalarına gereksinim olduğu düşünülmektedir. bilgi toplarken hangi kaynaklardan yararlanıldığı ve bu kaynakların güvenilir bilgiler sunup sunmadıkları önemlidir. 
Araştırma grubundaki öğrencilerin pek çoğu üniversite tercihlerini yaparken okul psikolojik danışmanlarından ve aile bireylerinden yardım aldıklarını belirtmektedirler. Bu bulguları sırayla branş öğretmenleri, internet, arkadaşlar, PDR öğrencileri, mezunlar, akademisyenler, tercih stantları izlemektedir. Hamamcı, Bacanlı ve Doğan (2013) çalışmalarında öğrencilerin mesleki ve eğitsel kararlarını verme sürecinde sırasıyla babalarına, annelerine, kitap dergi vb. yayınlara, okuldaki öğretmenlerine başvurdukları, bunları arkadaşlarının, diğer aile üyelerinin, dershanedeki öğretmenlerin, okul rehber öğretmenlerinin, dershane rehber öğretmeninin ve sinıf rehber öğretmeninin izlediğini bulmuşlardır. Özyürek ve Kılıç-Atıcı (2002) ise öğrencilerin en çok ailelerden, okuldaki ve dershanelerindeki, öğretmen ve rehber öğretmenlerinden, ÖSYM Yükseköğretim Programları ve Meslekler Rehberi (YPMR) kitabından ve dergilerden yararlandıKlarını belirlemişlerdir. Vurucu (2010) ise öğrencilerin sırasıyla aile, öğretmenler ve diğer okul personeli, arkadaş, çevresindeki kişilerden, mezunlar ve akrabalar gibi kaynaklardan yararlandıklarını belirtmektedir.Bu araştırmaların bulguları değerlendirildiğinde; öğrencilerin tercih sürecinde sırasıyla aileleri,okul psikolojik danışmanları,öğretmenleri, arkadaşları, mezunlar gibi kaynaklardan daha çok yararlandıkları görülmektedir. Bu özetlenen iki araştırmanın bulgularını bu sunulan araştırmanın bulguları desteklemektedir. Bulgular arasında en çok dikkat çekeni,ailelerin en az psikolojik danışmanlar kadar tercih sürecinde yararlanılan ya da etkili olan kaynaklar arasında yer almasıdır. Bu bulgu, kollektif kültüre sahip toplumlarda daha sık karşılaşılan ebeveynlerin çocuklarının karar verme süreçlerime müdahale etme ya da çocukların kararlarını ebeveynleriyle birlikte verme tutum ve davranışları sergilemelerinin suonuçlarıdır (Hamamcı, Bacanlı ve Doğan, 2013;). Dolayısıyla bu bulgu, Türkiye'de lokul psikolojik danışmanlarının özellikle meslek ve okul seçimi kararlarını verme süreçlerinde kariyer psikolojik danışmanlığı hizmetlerini sunarken bu hizmetlerin ailelere yönelik olanlarını mutlaka yapmaları gerektiğiönerilmektedir. Katılımcıların tercih sürecinde yaralandıkları kaynaklara ilişkin diğer bir dikkat çekici bulgu ise internetin ve diğer görsel-yazılı medya araçlarının sıklıkla yararlanılan kaynaklar arasında yer almasıdır. Ancak bu kaynaklar bilgiye erişimkolaylaştırırken doğru bilgi kaynağına ulaşmanın önemini de artırmaktadır. Bu nedenle tercih sürecindeöğrencileri YÖK ATLAS gibi güvenilir kaynaklara ve ISSKUR'un hizmetlerine yönlendirmek gerekmektedir.. Ayrıca bu 
araştırmanın bulguları, herhangi bir kaynaktan yardım almadan PDR programını tercih eden öğrencilerin de göz ardı edilemeyecek düzeyde olduğu görülmektedir. Bu bulgu, bu öğrencilerin eğitim sürecinde bölüm değiştirme ya da derslerde başarısızlık yaşama olasılıklarını ortaya koymaktadır Araştırma grubundaki öğrencilerin, pek çoğunun tercihlerini yaparken ikincil kaynak olarak ailelerinden yardım almaları da ilgili yerli ve yabancı literatürde lebeveynlerin ve diğer aile bireylerinin çocuklarının kariyer tercihlerine müdahale ettiklerini ortaya koyan araştırmaların bulgularıyla uyumludur (Bacanl, 2016; Gati ve Saka, 2001; Hamamcı ve diğ., 2013; Sürücü, 2005; Tien, 2001; Leung, Hou, Gati, ve Li, 2011 ).

Çalışma grubundaki öğrencilerin \%94'ünün aileleri PDR programını tercih etmelerini desteklerken, \%6'sının aileleri desteklememiştir. Bu bulgu, araştırmanın katılımcısı öğrencilerle aileleri arasında kariyer seçimi açısından uyum olduğunu göstermektedir.

Bu bulgular tercihlerini yaparken öğrencilerin pek çoğunun ailelerinden yardım aldıklarına ilişkin araştırmanın bir önceki bulgusuyla da uyumludur. Alan yazında aile desteğinin önemine dikkat çeken bazı araştırmalar bulunmaktadır. Sürücü (2005), lise öğrencilerinin ailelerinden den algıladıkları sosyal destek arttıkça mesleki olgunluklarının arttığını bulmuştur. McNair ve Brown (1983) ise anne-baba teşvikinin kariyer olgunluğu, mesleki umu ve beklentilerin yordanmasında önemli bir rol oynadığını belirtmektedirlerBu bulguılar aile desteğinin tercih sürecinde öğrencilerin kendilerine uygun kariyer kararı vermelerinde olumlu etkiler yaptığına işaret etmektedir.

$\mathrm{Bu}$ araştırmada çalışma grubundaki öğrenciler PDR alanını seçme nedenleri olarak insanlara yardım etmekten hoşlanmaya ve psikolojiye ilgi duymaya ilk sıralarda yer vermişlerdir. Bunları kişilik özelliklerine uygunluk, kolay istihdam imkanı, kişisel gelişim, gelecekteki ideallere uygunluk, mesleğin popülerliği, diğer tercihlere puanın tutmaması, çalışma koşullarının rahatlığı, aile isteği ve çalışma alanının genişliği gibi nedenler takip etmektedir.PDR programın tercih nedeni olarak son sıralarda ise, okul rehber öğretmeni olmak „, PDR eğitiminin kolay olması, maddi kazancının iyi olması ve okullarındaki psikolojik danışmanın model alınması yer almaktadır.. Bu sonuçlar önceki benzeri amaçla yapılan araştırmaların sonuçlarını desteklemektedir. Özer ve Avcı'nın (2013) araştırmasında PDR öğrencileri PDR programını iş bulma/atanma olasılığının fazla olması, kişiliklerine uygun olması, 
psikoloji bilimine ilgi duymaları, rehber öğretmenlerini örnek almaları, eğitiminin kolay olması, mesleğin saygınlığı, çalışma koşullarının rahatlı̆̆ı, cinsiyete uygunluğu ve puanlarınının PDR'yi seçmek için yeterli olması nedenleriyle seçtiklerini belirtmişlerdir. Aslan ve diğ. (2018) araştırmasında da PDR öğrencileri bu programı insanlara yardımcı olabilme, kişisel gelişimi sağlama, insan psikolojisini doğru olarak anlama, istihdam olanaklarının geniş olması ve eğitiminin ilgi çekici olması beklentileriyle ile tercih ettiklerini ifade etmişlerdir. TED (2017) çalışmasında ise PDR öğrencilerinin bu programı istihdam olanaklarının fazlalığı, alana ilgi duyma, insanlara yardımcı olup topluma yarar sağlama, kendini tanımaya/geliştirmeye yardım etmesi, insanlara-olaylara (nedenlerine) çok yönlü açlardan bakmayı öğrenmek, insanların problemlerini çözerek mutlu olmak ve psikoloji alanına yakın olması nedenleriyle seçtiklerini bulmuşlardır. Sarıkaya ve Khorshid (2009) ise üniversite öğrencilerinin eğitimini aldıkları mesleği; sevdikleri,, ilgi duydukları,kendi istek ve ideallerini gerçekleştireceği,, mesleğe yeteneklerinin uygunluğuaileleri istediği için, puanları yettiği için, toplumda saygın bir meslek olduğu için ve eğitimi basit ve kolay olduğu için seçtiklerini belirtmişlerdir. Korkut-Owen, Kepir, Özdemir, Ulaş ve Yllmaz (2012) ise, üniversite öğrencilerinin bölümlerini daha çok o mesleğe olan ilgileri, puanının o bölüme yetmesi, kişilik özelliklerine uygunluğu, iş bulma olasılığının yüksekliği, gelecekle ilgili amaçlarına uygunluğu, geçmişte bu alanda çalışan kişilerden etkilendikleri, kazanç sağlayabilecekleri ve prestijli bir meslek olduğu için seçtiklerini belirtmişlerdir. Gerek bu sunulan araştırmanın gerekse önceki araştırmaların sonuçları genel olarak değerlendirildiğinde; PDR öğrencilerinin PDR programını seçme nedenlerinin daha çok kişilik özelliklerine uygunluk, ilgilere uygunluk, gelecekteki ideallere uygunluk gibi kişisel faktörlerle ilgili olduğu görülmektedir. Bunu PDR mezunlarının istihdamlarının kolay olması, çalışma alanının geniş ve eğitiminin kolay olması gibi gibi politik, ekonomik ve eğitim sistemine ilişkin faktörlerin izlediği görülmektedir. $\mathrm{Bu}$ faktörlerin yanısıra aile isteği ve mesleğin popülerliği gibi sosyal faktörlere de yer verilmektedir.PDR öğrencilerinin PDR programını tercih nedenleri arasında bireysel faktörlere ilk siralarda yer verilmesi önemli bir bulgudur. Çünkü teorisyenler ve uygulayıcılar, bireyin kendine uygun meslek seçimi yapabilmesi için öncelikle ilgi, yetenek, değerleri gibi kişilik özelliklerini dikkate almasını önermektedirler (Bacanlı, 2019). Bu araştırmanın katılımcıları- 
nın büyük bir kısmının bu kuramsal görüşlere uygun meslek seçimi yaptıkları söylenebilir. Bununla birlikte bazı katılımclar, PDR'yi tercih nedenleri olarak YKS (Yükseköğretim Kurumları Sınavı) puanlarının sadece bu alana yeterli olduğu için seçtiklerini belirtmektedirler. Bu bulgu ise bazı öğrencilerin PDR programını sadece akademik başarılarını dikkate alarak tercih ettiklerini göstermektedir. Dolayısıyla bu bulgu, bu araştırmaya katılan öğrencilerin öncelikle dört yıllık PDR lisans programındaki dersleri ve içeriklerini, psikolojik danışmanlık mesleğinin temel özelliklerini tanıma gereksinimleri olduğunu düşündürmektedir..

Araştırman sonuçlarına dayanılarak, liselerde ve üniversitelerde sunulacak kariyer psikolojik danışamanlığı hizmetlerine ve ilerde yapılacak araştırmalara yönelik sunulabilecek bazı öneriler bulunmaktadır. Öncelikle, liselerde görev yapan okul psikolojik danışmanları, PDR hizmetlerini ve bu hizmetlerin rol ve işlevlerini tanıtmaya yönelik çalışmalara öncelik vermelidirler. Lise öğrencilerine yönelik kariyer psikolojik danışmanlığı ve rehberliği hizmetlerinde, PDR lisans programındaki dersleri, istihdam alanların ve bu alanlardaki güncel istihdam oranlarını tanıtan hizmetlerin sunulması önerilmektedir. Bu bilgileri edinmekiçin okul psikolojik danışmanları üniversitelerin PDR anabilim dallarıyla işbirliği yaparak yardım alabilirler. PDR 'nin istihdam alanları ve oranları hakkında ISSKUR'un ve benzerleri kurum ve kuruluşlerın kaynaklarından yararlanabilirler.Okul psikolojik danısmanlarınınm mesleklerin tanıtımıyla ilgili kariyer psikolojik danışmanlığı ve rehberliği hizmetlerini, öğrencilerin yanı sıra müşavirlik (konsültasyon) hizmetleri kapsamında öğretmenlere, okul yömeticilerine ve ailelere sunmaları önerilmektedir. psikolojik danışmanların iş yaşamında aaöğrencilere etkili kariyer psikolojik danışmanlığı ve rehberliği hizmetleri sunabilmeleri için üniversitelerin PDR ana bilim dallarında kariyer psikolojik danışmanlığ ve rehberliği alanıyla ilgili teorik, uygulamalı derslerin, süpervizyon eğitiminin ve okullarda yapılan uygulamalı derslerin çağdaş yöntem ve tekniklerle sunulması önerilmektedir.Özellikle MEB'nın ilgili birimlerinin ve üniversitelerin karyer gelişimi merkezlerinin psikolojik danışman adayı öğrencilere kariyer psikolojik danışmanlığı ve rehberliğiyle ilgili teorik ve uygulamalı derslerin çağdaş yöntem ve tekniklerle sunulması konularında destek vermeleri, gerekli durumlarda işbirliği yapmaları önerilmektedir. Ayrıca üniversitelerin PDR ana bilim dallarında, eğitim öğretimin başladığı ilk hafta birinci sınıf 
öğrencilerine oryantasyon hizmetlerinin sunulması önerilmektedir. Bu oryantasyon hizmetleri kapsamında,PDR ana bilim dalındaki öğretim üyelerini, PDR lisans programındaki teorik ve uygulamalı dersleiri,PDR nin istihdam alanlarını tanıtma ve benzeri etkinlikleri içeren hizmetlerin yapılması önerilmektedir. Okullarda çalışan PDR mezunlarının, rehber öğretmen veya rehberlik öğretmeni gibi öğrenciye psikolojik danışma hizmetlerinden çok öğretimi veya öğretmeni hatırlatan unvanlarla istihdamları yerine daha kapsayıcı olan ve PDR hizmetlerini sınırlandırmadan yansitan okul psikolojik danışmanı unvanıyla istihdam edilmeleri önerilmektedir. Ayrıca ilerde yapılacak araştırmalarda, PDR lisans programı birinci ve son sınıf öğrencilerinin tercih nedenlerine göre programdan memnuniyet düzeyleri boylamsal bir çalışma ile incelenebilir. Bunun yanında farklı lisans programlarını tercih eden öğrencilerin tercih nedenleri, tercih sürecinde programa ilişkin sahip olduğu bilgiler ve bilgi kaynaklarını incelemeye yönelik araştırmalar yapılabilir.

Bu sunulan araştırmanın ilgili literatüre teoriye ve pratiğe yönelik katkılarına rağmen bazı sınırılıkları bulunmaktadır. Araştırmanın verileri çevrimiçi/online ortamda toplandığından veriler, katılımcıların kendi motivasyonları ve soruları anlama düzeyleri ile sınırlıdır. Ayrıca araştırmaya yalnızca internet erişimi olan ve bilgisayar kullanabilen öğrenciler katılmışlardır. Diğer bir sınırlılık, araştırma katılımcıların öz bildirimlerine dayalı olduğundan sosyal beğenirlik faktörü sonuçları etkilemiş olabilir. Araştırma nitel bir araştırma olduğundan PDR ana bilim dalına yeni başlayan tüm birinci sınıf öğrencilerine genellenemez. 
EXTENDED ABSTRACT

\title{
Examining Preference Reasons of Undergraduate Students In Psychological Counseling and Guidance Programme
}

\author{
Feride Bacanlı - Abdullah Mücahit Aslan \\ Gazi University
}

The process from which the individuals chooses the profession until they finish their education comprise an important period of their career development. The more important it is for an individual to choose the right profession for him / herself, the more important it is for him / her to pursue his / her education successfully. However, especially in recent years, researches studied various countries and in Turkey found that many young people tend to give up their career decision while continuing their education (Bacanll, 2018; Bacanlı and Öztemel, 2017a; Bacanlı and Öztemel, 2017b; Salman, 2018; Tien, 2001; Tien, 2005). It is observed that most of the students who have just started training have chosen this programme without searching enough in the Psychological Counseling and Guidance (PDR) Program. These observations also are supported by researches (Salman and Kan, 2018). In the study of Bacanl and Salman (2018) found that the client who was undergraduated student at the PDR programme had career decision making diffculties choosing the PCG without necessary and sufficient information. It is also seen that most students at the PDR want to change their preferences at the first grade and two grade (Aslan, Koç and Büyüksevindik, 2018). Department change desire of students decreases through the third grade. Nevertheless, the career indecision in first two years negatively affects the adjustment to university and training programme, and naturally also negatively affects their academic success. Therefore, the aim of this study is to determine the reasons why undergraduate first year students in the Psychological Counseling and Guidance (PDR) program prefer PDR. It is thought that the results of this research will be used in career guidance and counseling services to be offered in high schools and universities. Besides, it is expected that the results of this research will suggest several implications for future theorical research and practice. 
The phenomenology design from qualitative research methods is used in this study. The criterion sampling method, one of the purposeful sampling methods, was used to form the study group. In the study, it was taken as a criterion that the first grade students of PDR did not participate in the orientation studies conducted by the PDR programs at the beginning of the academic year. Students who met this criterion were included in the research group. The study group consisted of 200 volunteer students in PDR program of 10 universities in Turkey. The datas was collected using the online question form in the days prior to orientation studies in PDR program. The question form was developed by researchers. It consists of 10 questions, 8 open-ended and 2 closed-ended. Data were analyzed using content analysis,and data were converted to numerical values such as frequency and percentage.

The results showed that the participants perceive the school counselors perform their duties at school by providing psychological support, solving problems of students, efficient study skills. The results showed that school counselors work outside school at the courthouses, private companies, Guidance Research Centers, Turkish Armed Forces, hospitals and private clinics. The participants defined the guidance teacher as the person who graduated from the PDR program, who helped solve psychological problems and guided the student. Findings regarding the order of preference of the PDR program showed that the PDR program was the first choice of the majority of the participants. Their subsequent preferences are law and psychology. Findings about the institutions and persons from where/who they get help during their university program preference showed that the participants got help from the school counselors, family members, branch teachers, and internet. The findings of the participants' reasons for choosing the PDR program showed that personal factors such as helping people and interest in psychology were most influential in their choice. This was followed by political, economic and educational factors such as ease of employment, good financial gain, and easy education. In addition to these factors, social factors such as family influence and the popularity of the profession affected the preferences of the participants.

The aim of this research is to determine the reasons of preference of first grade students in PDR program. Generally, the results of the study indicated that the majoritiy of participants have some misperceptions and knowledge about the duties of the counselors, the institutions they work outside of 
school, the conceptions of guidance teacher and psychological counselor, but they generally have sufficient knowledge. In addition to these, it found that some participants have mixed conceptions about the PDR program and psychology program. The majority of participants stated the PDR as first preference. This results indicate that they have preferred the PDR program consciously. Besides, most of the participants stated that they preferred the PDR program because it was compatible with their own interests and personalities. Personal factors are followed by political, economic and educational factors such as the possibility of easy employment, wide possibilities of employment and easy education. Besides these factors, it was reached that social factors such as family desire and popularity have effect. As a recommendation, it may be suggested that school counselors working in high schools should prioritize studies to introduce their roles and functions in PDR services in schools. In addition, it is recommended that the PDR programs in the universities providing psychological counseling training should provide more equipped trainings in the field of vocational guidance and career counseling and give more importance to practice, internship and supervision.

\section{Kaynakça / References}

Aslan, A. M., Koç, H. ve Büyüksevindik, B. (2018). Psikolojik danışma ve rehberlik lisans programı 1.sını öğrencilerinin programa ilişkin beklentileri. MANAS Sosyal Araştırmalar Dergisi, 7 (3), 143-160.

Bacanl, F. (2016). Career decision-making difficulties of turkish adolescents. International Journal for Educational and Vocational Guidance, 16, 233-250. doi: 10.1007/s10775-015-9304-8.

Bacanl, F. ve Öztemel, K. (2017a, Ekim). Kariyer karar verme güçlükleri ve kariyer karar verme profilleri arasındaki ilişkiler. II. INES Uluslararası Akademik Araştırmalar Kongresi'nde sunulmuş bildiri, Alanya.

Bacanl, F. ve Öztemel, K. (2017b, Nisan). Kariyer karar verme güçlükleri ölçeğinin genç yetişkin örnekleminde faktör yapısının ve güvenirliğinin incelenmesi. 26. Uluslararası Ĕ̆itim Bilimleri Kongresi'nde (ICES/UEBK-2017) sunulmuş bildiri, Antalya.

Bacanl, F. ve Salman, N. (2018, Ekim). Üç aşamalı kariyer karar verme modeline dayalı kariyer psikolojik danışma: Vaka çalışması. 20. Uluslararası Psikolojik Danışma ve Rehberlik Kongresi'nde (PDRkongre2018) sunulmuş bildiri, Samsun. 
Bacanl, F. (2018, Haziran). Hope and social-contextual variables as predictors of career adaptability in turkish young adult. Society for Vocational Psychology 13th Biennial Conference'da sunulmuş bildiri, The Sagura Hotel, Scottdale, Arizona, USA.

Bacanl, F. (2019). Özellik faktör uyumlu kuramlar. Binnur Yeşilyaprak (Ed.). Mesleki rehberlik ve kariyer danışmanlığı: Kuramdan uygulamaya (10. Baskı) içinde (s. 90127). Ankara: Pegem Akademi.

Eren-Gümüş, A. (2018). Okul psikolojik danışmanlarının rollerine ilişkin okul yöneticilerinin algıları: Bir karma yöntem araştırması. Mersin Üniversitesi Eğitim Fakültesi Dergisi, 14(1), 151-168.

Erlandson, D.A., Harris, E.L., Skipper, B. L., ve Allen, S. T. (1993). Doing naturalistic inquiry: A guide to methods. Beverly Hills, CA: Sage.

Gati, I., ve Saka, N. (2001a). High school students' career related decision-making difficulties. Journal of Counseling and Development, 79, 331-340. doi:10.1002/j.1556-6676.2001.tb01978.x.

Hamamcı, Z., Bacanlı, F. ve Doğan, H. (2013). İköğretim ortaöğretim ve üniversite öğrencilerinin mesleki ve eğitsel kararlarını etkileyen faktörlerin incelenmesi. Elektronik Sosyal Bilimler Dergisi, 12(44), 284-299.

Karataş, Z. ve Şahin-Baltacı, H. (2013). Ortaöğretim kurumlarında yürütülen psikolojik danışma ve rehberlik hizmetlerine yönelik okul müdürü, sınıf rehber öğretmeni, öğrenci ve okul rehber öğretmeninin (psikolojik danışman) görüşlerinin incelenmesi. Ahi Evran Üniversitesi Kırşehir Eğitim Fakültesi Dergisi, 14(2), 427-460.

Kepçeoğlu, M. (1994). Psikolojik damışma ve rehberlik. Ankara: Özerler.

Korkut-Owen, F. ve W.Owen, D. (2008). School counselor's role and functions: school administrators' and counselors' opinions. Ankara Üniversitesi Eğitim Bilimleri Fakültesi Dergisi, 41(1), 207-221.

Korkut-Owen, F., Kepir, D. D., Özdemir, S., Ulaş, Ö. ve Yılmaz, O. (2012). Üniversite öğrencilerinin bölüm seçme nedenleri. Mersin Üniversitesi Eğitim Fakültesi Dergisi, 8(3), 135-151.

Kuzgun, Y. (2008). Rehberlik ve psikolojik damışma. Ankara: Nobel.

McNair, D. ve Brown, D. (1983). Predicting the occupational aspirations, occupational expectations, and career maturity of black and white male and female 10th graders. The Vocational Guidance Quarterly, 32, 29-36.

Mersin, S. ve Öksüz, E. (2014). Üniversite öğrencilerinde aile desteğinin kayg düzeyine etkisi. Uluslararası Sosyal Araştırmalar Dergisi, 7(35), 643-650. 
Meşeci, F., Dinçer, D. ve Çırakoğlu, B. (2006). Illköğretim ve ortaöğretim öğrencilerinin okul psikolojik danışma ve rehberlik servisine ve çalışanlarına yönelik algiları. Hasan Ali Yücel Eğitim Fakültesi Dergisi, 3(2), 175-186.

MEB. (1981). Onuncu milli eğitim şurası raporu. Ankara: MEB Yayınları.

Öcal, G. (2010). Hacettepe üniversitesi psikolojik danışma ve rehberlik lisans programı mezunlarmin mezun oldukları programa ilişkin görüşleri. Yayınlanmamış yüksek lisans tezi, Hacettepe üniversitesi, Ankara.

Özer, A. ve Avcı, D. (2015, Ekim). Psikolojik danışma ve rehberlik öğrencilerinin üniversite seçimini etkileyen faktörler. 13. Ulusal Psikolojik Damışma ve Rehberlik Kongresi'nde sunulan bildiri. Mersin Üniversitesi, Mersin.

Özgüven, B.E. (1990). Ülkemizde psikolojik danısma ve rehberlik faaliyetlerinin dünü ve bugünü. Türk Psikolojik Damışma ve Rehberlik Dergisi, 1 (1), 4-15.

Özyürek, R. ve Kılıç-Atıcl, M. (2002). Üniversite öğrencilerinin meslek seçimi kararlarında kendilerine yardım eden kaynakların belirlenmesi. Türk Psikolojik Danışma ve Rehberlik Dergisi, 2(17). 33-42.

Salman, N. ve Kan, A. (2018, Nisan). Üniversite öğrencilerinin kariyer karar verme güçlüklerinin çeşitli değişkenlere göre incelenmesi. III. INES Uluslararası Eğitim ve Sosyal Bilimler Kongresinde sunulmuş bildiri, Antalya.

Salman, N. (2018). Kariyer karar verme güçlüklerinin, kariyer engelleri, kariyer karar verme öz yetkinliği ve karar durumu ile ilişkisi. Yayınlanmamış yüksek lisans tezi, Gazi üniversitesi, Ankara.

Sarıkaya, T. ve Khorshid, L. (2009). Üniversite öğrencilerinin meslek seçimini etkileyen etmenlerin incelenmesi: Üniversite öğrencilerinin meslek seçimi. Türk Ĕ̈itim Bilimleri Dergisi, 7(2), 393-423.

Super, D. E. (1990).A life span,life-space approach to career development. In D. Brown,ve L.Brooks (Eds.), Career choice and development ( ${ }^{\text {nd }}$ ed). 197-261. San Francisco: Jossey-Bass.

Sürücü, M.(2005). Lise öğrencilerinin mesleki olgunluk ve algladıkları sosyal destek düzeylerinin incelenmesi. Yayımlanmamış yüksek lisans tezi, Gazi Üniversitesi, Ankara.

T.E.D., (2017). Programa ilişkin öğrenci görüşleri anket sonuçları. TED Üniversitesi Rehberlik ve Psikolojik Danışmanlık Programı Araştırma Raporu.

Tien, H. -L. S. (2001). Career decision-making difficulties perceived by college students in taiwan. Bulletin of Educational Psychology, 33(1), 87-98.

Tien, H.-L. S. (2005). The validation of the career decision-making difficulties scale in a chinese culture. Journal of Career Assessment, 13, 114-127. doi:10.1177/1069072704270327. 
Ültanır, E. (2005). Türkiye'de psikolojik danışma ve rehberlik (pdr) mesleği ve psikolojik danışman eğitimi. Mersin Üniversitesi Eğitim Fakültesi Dergisi, 1(1), 102-111.

Vurucu, F. (2010). Meslek lisesi öğrencilerinin meslek seçimi yeterliliği ve meslek seçimini etkileyen faktörler. Yayınlanmamıs yüksek lisans tezi, Yeditepe üniversitesi, İstanbul.

Yelken, K. (2008). Orta öğretim son smmföğrencilerinin üniversite tercihlerini ve meslek seçimini etkileyen faktörler: Sakarya il merkezi örneği. Yayınlanmamış yüksek lisans tezi, Sakarya üniversitesi, Sakarya.

Yeşilyaprak, B. (2007). Türkiye'de psikolojik danışma ve rehberlik alanının gelişiminde türk psikolojik danışma ve rehberlik derneğinin yeri ve önemi. R. Özyürek (Yay. Haz.). Gelişen psikolojik danışma ve rehberlik (Cilt 1) içinde (s. 55-66). Ankara: Nobel Yayıncilik.

Yeşilyaprak, B. (2013). 21. yüzyılda eğitimde rehberlik hizmetleri: Gelişimsel yaklaşım. Ankara: Nobel Yayınclik.

Yıldırım, A. ve Şimşek, H. (2018). Sosyal bilimlerde nitel araştırma yöntemleri. Ankara: Seçkin Yayınalik.

Zimpfer, D. G. (1996). Five year follow up doctoral graduates in counseling. Counselor Education and Supervision, 35(3), 218-230.

Leung, S. A., Hou, Z.-J., Gati, I. ve Li, X. (2011). Effects of parental expectations and cultural-values orientation on career decision-making difficulties of Chinese university students. Journal of Vocational Behavior, 78, 11-20. doi:10.1016/j.jvb.2010.08.004.

\section{Kaynakça Bilgisi / Citation Information}

Bacanlı, F. ve Aslan, A. M. (2020). Psikolojik danışmanlık ve rehberlik lisans programı öğrencilerinin bu programı tercih nedenlerinin incelenmesi. OPUS-Uluslararası Toplum Araştırmaları Dergisi, 16(28), 929-961. DOI: $10.26466 /$ opus.667847 